\title{
Integration of Multiple Data Sources to Simulate the Dynamics of Land Systems
}

\author{
Xiangzheng Deng ${ }^{1,2}$, Hongbo $\mathrm{Su}^{1}$ and Jinyan $\mathrm{Zhan}^{3, *}$
}

1 Institute of Geographical Sciences and Natural Resources Research, Chinese Academy of Sciences, Beijing, 100101, P.R. China; E-mails: dengxz.ccap@igsnrr.ac.cn; suhb@igsnrr.ac.cn

2 Center for Chinese Agricultural Policy, Chinese Academy of Sciences, Beijing, 100101, P.R. China

3 Beijing Normal University, Beijing, 100875, P.R. China

* Author to whom correspondence should be addressed; E-mail: zhanjy@bnu.edu.cn; Fax: (8610)6485-6533

Received: 25 December 2007 / Accepted: 24 January 2008 / Published: 4 February 2008

\begin{abstract}
In this paper we present and develop a new model, which we have called Dynamics of Land Systems (DLS). The DLS model is capable of integrating multiple data sources to simulate the dynamics of a land system. Three main modules are incorporated in DLS: a spatial regression module, to explore the relationship between land uses and influencing factors, a scenario analysis module of the land uses of a region during the simulation period and a spatial disaggregation module, to allocate land use changes from a regional level to disaggregated grid cells. A case study on Taips County in North China is incorporated in this paper to test the functionality of DLS. The simulation results under the baseline, economic priority and environmental scenarios help to understand the land system dynamics and project near future land-use trajectories of a region, in order to focus management decisions on land uses and land use planning.
\end{abstract}

Keywords: Land use, land use change, dynamics of land systems, simulation, scenario analysis 


\section{Introduction}

The dynamics of a land system is a comprehensive process which operates over a range of scales in space and time and is driven by more than one variable that can influence the actions of the agents of land uses [1-4]. It is of great importance to simulate the dynamics of land systems, which can greatly benefit decisions making about land management and land use planning. A number of previous investigations have focused specifically on this field $[2,5-8]$. Most of the models created for land project change uses can be categorized into three types: semi-empirical models, cellular automata models and agent-based models [9-12]. Semi-empirical models use statistical techniques to derive the mathematical relationships between variables, identifying land use changes and sets of explanatory variables of land use changes [9, 13]. The consideration of co-linearity between the explanatory variables, however, is always ignored in semi-empirical models. Cellular automata models consist of an environment in which the interactions occur among individuals, which are defined by behavioural rules and characteristics of grid cells of land uses. However, the impacts from time variant variables on the land uses changes are sometime overlooked in the simulation process [14]. In agent-based modeling, land use changes are regarded depending on characteristics of a region that are of socioeconomic and biophysical origin and are affected by the behaviors of the land stakeholders and their decisions. The reduction of the complexity inherent in land systems to more simple relationships in agent-based modelling would lead to large bias contained in the simulation results [10]. In addition, an agent-based model requires programming in an object-orientated language such as Java. That is, it requires a level of computing skill beyond simple spreadsheet programming and by now some agentbased software frameworks have been developed to ease the task of the social scientist or business analyst in building agent-based models.

In this paper we present a new model, called Dynamics of Land System (DLS), which is capable of solving the problems of the currently available methods, and of integrating multiple data sources to simulate the dynamics of land systems. There are two special features in DLS. One is that it reaches a balance by incorporating a dual-level strategy: a scenario analysis of land demand at a regional level and a spatial desegregation of land uses at a detailed pixel level. The other is shown as the consideration of the interactions between influencing factors on land uses and the interactions between neighbour pixels for these influencing factors.

Given the complexity of land systems, which is determined and represented by the interactions between land and land users, DLS, at the very top level, integrates five dimensions of influencing factors - variability of geophysical conditions, environmental changes, trade environment changes, institutional changes and policies closely related with land management (Figure 1). At the bottom level, parameters identifying the technical changes, lifestyle changes, economic growth, population growth and urbanization are also incorporated in the model framework of DLS. Besides, scenarios of land use changes are developed and the changes of land uses are spatially disaggregated into each grid cell in accordance with the estimated relationships between land uses and their influencing factors. DLS is implemented as a user friendly software tool which provides users with options to define land use change scenarios and format the input parameters and edit the regression results between land uses and their influencing factors by including a shell with menu bars, view windows, etc. (Figure 1) 
Figure 1. Modeling framework of DLS.

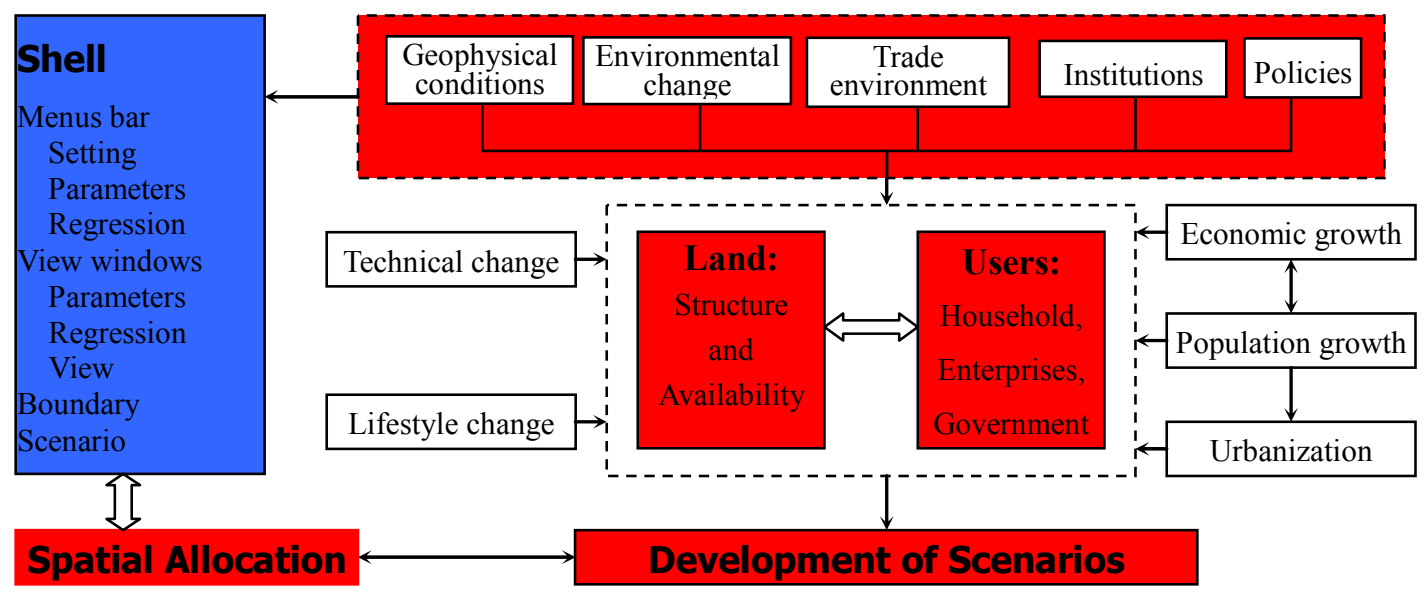

The key modules of DLS are described in Section 2. DLS is then used in Section 3 to perform a case study on the Taips County in Inner Mongolia in northern China as a demonstration of the functions of DLS. The results are analyzed in Section 4 and conclusions based on the case study are given in Section 5.

\section{Methodology}

There are three main modules in DLS: a spatial regression module to identify the relationships between land uses and their influencing factors; a scenario analysis module of land use changes as required by the demands of land uses at the regional level and a spatial disaggregation module to allocate land use changes from a regional level to the disaggregated grid cells.

\subsection{Assumptions}

To simulate the dynamics of land systems three assumptions are required in DLS. These assumptions include: (1) each patch of land is theoretically convertible [15]; (2) the land use changes occur only under agricultural production supply conditions, or in other words, certain kinds of land uses, cannot meet the land demand during a simulation period [5] and (3) the trajectories of land use changes are affected only by land uses in the base year, the initial year for the simulation, and the changes of the influencing factors during simulation period [16].

\subsection{Scenario analyses}

The scenario module provides one of the indispensable inputs in DLS. By including the scenario analyses of land use changes, DLS can export more than one set of spatially explicit simulation results of the land use change dynamics. The scenario module of DLS considers the specific needs for the case area. Trend analyses methods, e.g. linear interpolations or more sophisticated econometric models, are used to develop the scenarios of land use changes during simulation period. For example, in the case study of the Taips County, the trajectories of land use changes in the projection period are derived 
by an interpolation process based on a reference condition from a field trip/household survey and a regional land use planning made by local government.

\subsection{Spatial regression analyses}

The spatial regression analysis provides the model with regression functions to explore the relationship(s) between land uses and their influencing factors. A fitted logistic regression function with the spatial lag terms of influencing factors to measure the relationship between the influencing factors and land uses can be represented in the logit form. The interactions between factors influencing land uses and the interactions between adjacent pixels with some certain kinds of land uses are incorporated by including the collinear diagnostics in the spatial lag terms (Equation 1), respectively. All the influencing factors and the information on the base year's land uses are incorporated in the regression functions.

$$
\pi=\frac{\exp \left(b_{0}+\sum_{j=1}^{n} b_{j} X_{j}+\sum_{j=1}^{n} \rho W_{m n} X_{j}\right)}{1+\exp \left(b_{0}+\sum_{j=1}^{n} b_{j} X_{j}+\sum_{j=1}^{n} \rho W_{m n} X_{j}\right)}
$$

where $X$ is the vector of factors influencing land uses, and $\pi$ identifies the occurrence probability of a grid cell for the considered land use type $j . W_{m n}$ is the spatial weight identifying the neighborhood between $m$ and $n . \rho$ is the estimated coefficient of spatial lag term of $X_{j}$. A unit increase of the influencing factors is associated with an increase in the $\exp \left(b_{j}\right)$ plus $\exp \left(\varrho W_{m n}\right)$ components of the occurrence probability of the considered land uses. $b_{j}$ is the estimated coefficient of $X_{j} . b_{0}$ is the residual constant of the equation.

\subsection{Conversion rule}

The conversion rule in DLS determines which conversions are allowed for a certain kind of land use or where, identified by a number of grid cells, conversions of land uses which results in direct land use changes could occur. It is a possible value, an indispensable input parameter, which describes the temporal behavior of land use types or the status of the grid cells [17]. The setting of the conversion rule is done by assigning a value between 0 and 1, where 0 means all changes are allowed and 1 means that it is prohibited for the current land use type to be converted into other land uses. This value of 1 is given to the land use types, or a number of grid cells, which are difficult to convert, e.g., urban settlements (which are not likely be converted back into agriculture). If the demand for a certain land use type decreases, the possibility of converting land allocated to other land use types back to this kind of land use type will be lowered accordingly. This setting strategy can stabilize the land system. The higher the value of a conversion rule is, the more difficult it is for this kind of land use type in a number of grid cells to be converted to other uses. 


\subsection{Spatial disaggregation of land-use changes}

Following the strategy on modeling procedures of land use changes developed by Verburg et al. [17], we incorporate a module for spatially disaggregating land use changes in DLS. The spatial disaggregation module is mainly affected by the settings of conversion rule, the existence probability of each kind of land use at each grid cell and demands of each kind of lands at regional level. Land use type or location specific conversion rules can be specified by the user of DLS. The conversion rules are enforced to give each land use type a certain level of resistance to change. Three different situations can be distinguished for each land use type:

Situation 1: For some land use types it is not likely that they can be converted into another kind of land use after their initial conversion. Under such circumstances, unless a decrease in area demand for this land use type occurs, the areas covered by this kind of land use are no longer evaluated for potential land use changes. In this situation, it also holds that if the demand for this land use type decreases, there is no possibility of expansion of this land use type in other areas.

Situation 2: Those land use types with the small value of 0 for the conversion rule can be converted very easily. Cultivated land, for example, is easy to be converted into another land use type if there is no strict protection of cultivated land. When this situation is chosen for a land use type, there will be no restrictions for this kind of land use type converted into other types.

Situation 3: There are also a number of land use types that operate between situation 1 and situation 2. For example, given the high investment required for their establishment, permanent plantations are therefore not likely to be converted soon after they have been converted from another land use type [17]. However, in the end, when another kind of land use type becomes more profitable it is possible that a conversion will occur. This situation is simulated by defining a relative elasticity for change $(R E)$ for the land use type considered ranging between 0 (similar to situation 2) and 1 (similar to situation 1). The higher the defined elasticity, the more difficult it can be converted to other land use types. The spatial disaggregation of land use change is achieved in an iterative procedure in according to the following steps:

1. The initial step is to determine which grid cells are allowed to change. Grid cells that are either within a protected area or of one kind of land use type that is not allowed to change (situation 1 above) are excluded from further calculation.

2. For each grid cell $i$ the total probability $\left(T P_{i, j}\right)$ is calculated for land use types $j$ according to the following equation:

$$
T P_{i, j}=R E_{j}+I T_{j}+\pi_{i j}
$$

where $R E_{j}$ is the relative elasticity for change specified in the conversion rules and is only given a value if grid cell $i$ is already under land use type $j$ in the year considered. $R E_{j}$ equals zero if all changes are allowed. $I T_{j}$ is an iteration variable that is specific to the land use type $j$ and a preliminary evaluation is made with an equal value of $I T_{j}$ for all land use types by evaluating the land use types with the highest total probability for the considered grid cell. $\pi_{i j}$ is the occurrence probability of the land use type $j$ in the grid cell of $i$, which is further determined by the integrated effects from the influencing factors estimated in the spatial regression. 
3. The total disaggregated area of each land uses is now aggregated and compared to the demands of land uses under a certain kind of scenario at the regional level. For land use types where the allocated area is smaller than the demanded area the value of the iteration variable of land use type $j, I T_{j}$, is increased. For land use types for which too much is allocated, the value is decreased.

4. Steps 2 to 3 are repeated as long as the demands of land uses at the regional level are not fulfilled. When the aggregated area of land uses meet the demands of each kinds of land use the disaggregation procedure will stop and a final disaggregated land use map would be saved and exported and then the disaggregation procedure move to the simulation for another kind of scenarios.

\section{Application of the DLS Model}

A case study wss conducted in Taips County to test the functionality and illustrate the procedures to integrate the multiple data sources to simulate the dynamics of land systems. Taips County is located in in the farm-pasture transitional belts in the central part of Inner Mongolia. Its geographical location is from $114^{\circ} 51^{\prime}$ to $115^{\circ} 49^{\prime}$ East Longitude and $41^{\circ} 35^{\prime}$ to $42^{\circ} 10^{\prime}$ North latitude (Figure 2), with a total area of $3415 \mathrm{~km}^{2}$. With the population growth and the deterioration of environmental conditions, the stress on limited land and water resources is increasing, which further result in the dramatic changes of land uses.

Figure 2. Location of Taips County in North China.

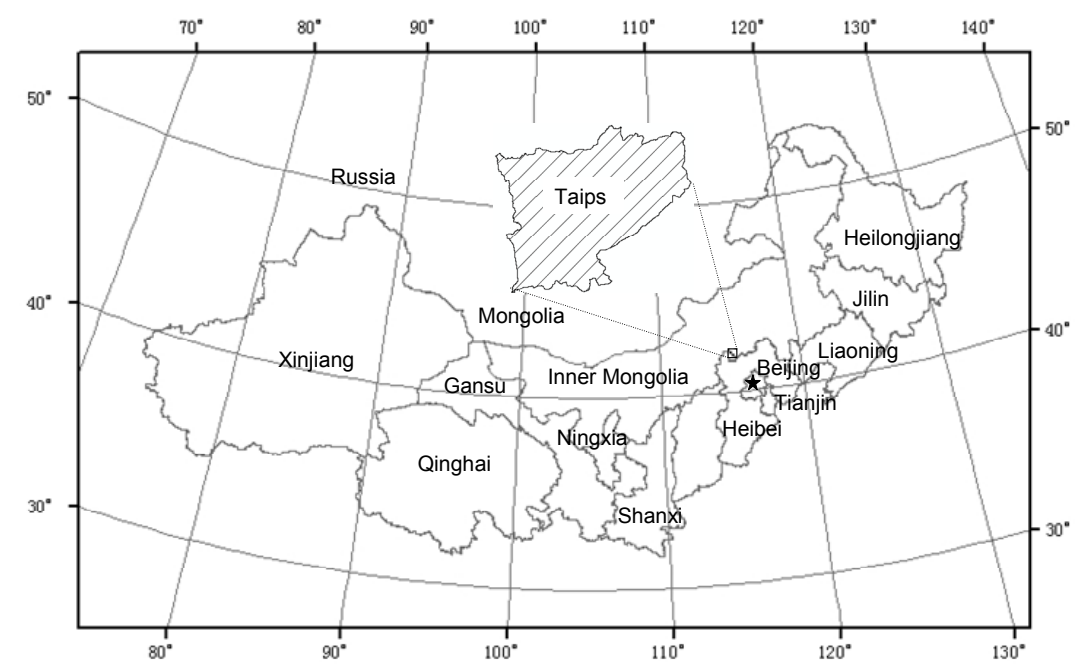

\subsection{Data and processing}

\subsubsection{Dependent variables}

The original land use map of Taips County (Figure 3a) was derived from Landsat Tematic Mapper images in 1995 and then land uses were reclassified and expressed in a special representation scheme. In the new land use scheme, the land use type is expressed by binary values of 1 or 0 for each grid cell of $100 \times 100$ meters to show the existence/non-existence of that kind of land use. The dependent 
variables for the spatial regression between land use and influencing factors in Taips County are listed in Table 1 and Figure $3 b$.

Table 1. Reclassification of land uses.

\begin{tabular}{|c|c|c|}
\hline Code & Land use & Description \\
\hline 0 & Cultivated land & Original data include both paddy and non-irrigated uplands. \\
\hline 1 & Forestry area & $\begin{array}{l}\text { Natural or planted forests with canopy covers greater than } 30 \% \text {; land } \\
\text { covered by trees less than } 2 \mathrm{~m} \text { high, with a canopy cover greater than } 40 \% \text {; } \\
\text { land covered by trees with canopy cover between } 10 \text { to } 30 \% \text { and land used } \\
\text { for tea-gardens, orchards and nurseries. }\end{array}$ \\
\hline 2 & Grassland & $\begin{array}{l}\text { Lands covered by herbaceous plants with coverage greater than } 5 \% \text { and } \\
\text { land mixed rangeland with the coverage of shrub canopies less than } 10 \% \text {. }\end{array}$ \\
\hline 3 & Water area & $\begin{array}{l}\text { Land covered by natural water bodies or land with facilities for irrigation } \\
\text { and water reservation, including rivers, canals, lakes, permanent glaciers, } \\
\text { beaches and shorelines, and bottomland. }\end{array}$ \\
\hline 4 & Built-up area & Land used for urban and rural settlements, industry and transportation. \\
\hline 5 & Unused land & All other lands. \\
\hline
\end{tabular}

Figure 3. Land use map of Taips County in 1995, (a) Synthetical representation of land uses; (b) Representation of the land uses by binary values of 1 or 0 , b0 to b5.

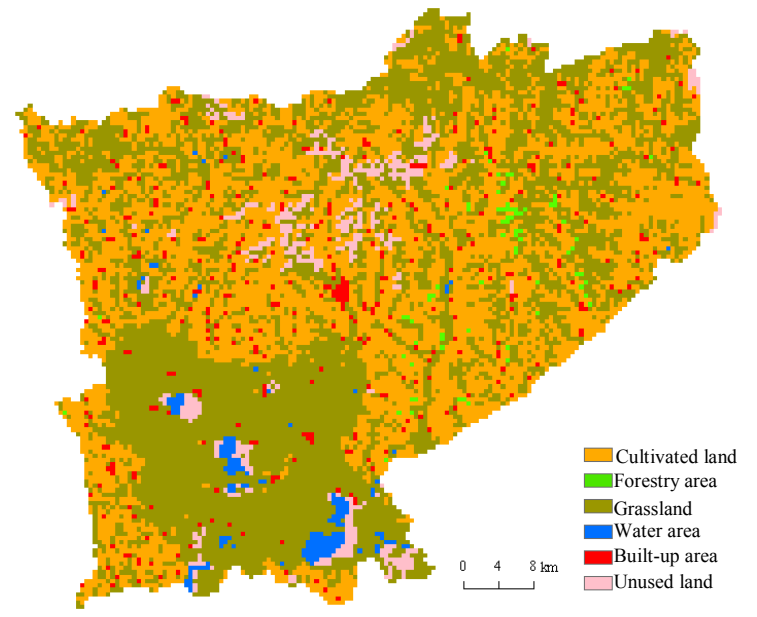

(a)

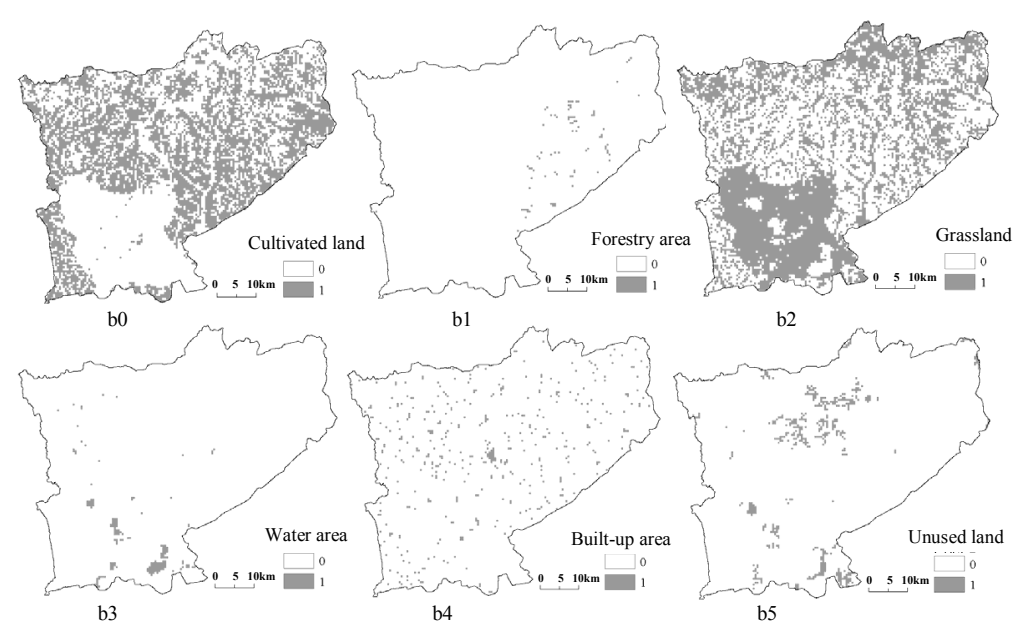

(b) 


\subsubsection{Influencing factors of land uses in Taips County}

As discussed earlier, the dynamics of a land system are actually influenced by a couple of factors. In this case study, the influencing factors can generically be categorized into four kinds: geophysical, climatic, proximity and socio-economic variables (see Table 2).

Table 2. Influencing factors of land uses considered in DLS in the case study of Taips County.

\begin{tabular}{|c|c|}
\hline Influencing factors & Definitions (units between parentheses) \\
\hline \multicolumn{2}{|l|}{ Geophysical variables } \\
\hline Terrain & $\begin{array}{l}0: \text { Hills } \\
\text { 1: Plain } \\
\text { 2: Mesa } \\
\text { 3: Plateau }\end{array}$ \\
\hline Soil $\mathrm{pH}$ value & $\begin{array}{l}\mathrm{pH} \text { values of soil. The higher the value is, the lower the acidity of } \\
\text { the soil. }\end{array}$ \\
\hline Depth of soil & Depth of top soil $(\mathrm{cm})$ \\
\hline Elevation & Digital Elevation Model (m) \\
\hline Slope & Terrain slope derived from DEM (0.01 degrees) \\
\hline \multicolumn{2}{|l|}{ Climatic variables } \\
\hline Air temperature & Mean annual temperature $\left(0.1^{\circ} \mathrm{C}\right)$ \\
\hline $\begin{array}{l}\text { Cumulated temperature }(\geq 0 \\
\text { degrees Centigrade) }\end{array}$ & $\begin{array}{l}\text { Annually cumulated temperature of daily mean air temperature } \\
\text { above } 0{ }^{\circ} \mathrm{C}\left(0.1^{\circ} \mathrm{C}\right)\end{array}$ \\
\hline $\begin{array}{l}\text { Cumulated temperature } \\
(\geq 10 \text { degrees Centigrade) }\end{array}$ & $\begin{array}{l}\text { Annually cumulated temperature of daily mean air temperature } \\
\text { above } 10{ }^{\circ} \mathrm{C}\left(0.1^{\circ} \mathrm{C}\right)\end{array}$ \\
\hline Sun-shining hours & Sunshine hours rectifying the spatial variability of solar radiation \\
\hline \multicolumn{2}{|l|}{ Proximity variables } \\
\hline Distance to province capital & Geometric distance to nearest province capital \\
\hline Distance to the highway & Distance to the nearest highway $(\mathrm{km})$ \\
\hline Distance to the expressway & Distance to the nearest expressway $(\mathrm{km})$ \\
\hline \multicolumn{2}{|l|}{ Socio-economic variables } \\
\hline Population density & $\begin{array}{l}\text { Interpolated population density (persons } / \mathrm{km}^{2} \text { ) based on the } \\
\text { Surface Modeling of Population Distribution [18]. }\end{array}$ \\
\hline GDP & $\begin{array}{l}\text { Interpolated values of Gross Domestic Product (GDP) (10000 } \\
\text { yuan } / \mathrm{km}^{2} \text { ) based on the spatially explicated analyses on the } \\
\text { relationship between economic growth level and factors that might } \\
\text { affect economic growth [19] }\end{array}$ \\
\hline
\end{tabular}

1) Geophysical variables

In accordance with the practical circumstances of Taips County and the data requirements of DLS, all the terrain conditions are aggregated to four categories, and then a lookup table is made to convert terrain types into a new representation scheme, using the binary values of $1 / 0$ to identify the existence 
or non-existence for some certain kind of terrain conditions in each grid cell. The rest of the geophysical variables, soil $\mathrm{pH}$ values, depth of soil, elevation and terrain slope are with the continuous values for each grid cell to identify the regional difference of the geophysical conditions.

2) Climatic variables

All the climatic variables are generated from the site-based observations from the China Meteorological Administration. The spline interpolation algorithm is employed to make the surface data of climatic variables acquired at observation stations $[20,21)$. The values for the climatic variables during simulation period are estimated using the space-time stochastic model [22].

\section{3) Proximity variables}

Proximity variables including the distance from each pixel to the nearest provincial capital or highway, provincial road and county road are incorporated into surface to measure the impacts of the infrastructure facility on the dynamics of land systems. GIS software is used to calculate the proximity variables, based on the geographical database, including the road network and the location information of major cities around the case study area. Figure 4 shows the spatial variability of the distance of each pixel to the national expressway and the nearest provincial capitals.

Figure 4. Distance from the centroids of each grid cell to the national expressway (a) and the nearest provincial capital (b) in the boundary of Taips County.

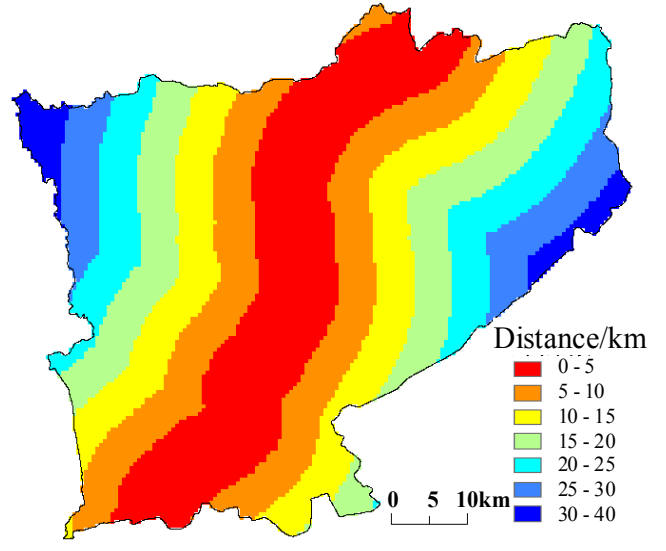

(a)

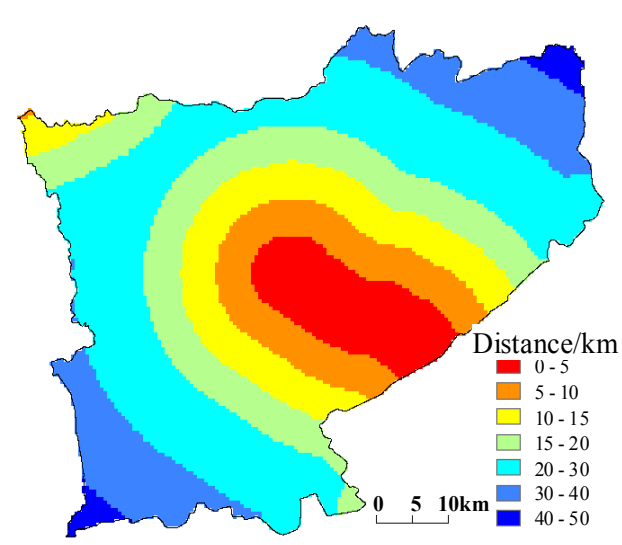

(b)

4) Social and economic variables

Social and economic variables, population density and gross domestic product (GDP) originally aggregated at the township level, are also spatially interpolated into the surface data. The historical data on the population and GDP are collected based on the household survey and field trip. The trends for the population growth and GDP expansion are projected based on the regional long-term planning of Taips County. 


\section{Results}

\subsection{Estimations of the coefficients of the influencing factors}

The relationship between land uses and influencing factors is explored based on the spatial regression analyses since the year 2000. The regression coefficients identifying the effects from influencing factors on the land uses of cultivated land, forestry area, grassland, water area, built-up areas and unused land of Taips County in the year 2000 are listed in the column 1 to 6 of Table 3, respectively.

Table 3. Regression coefficients of influencing factors of land uses in Taips County, 2000.

\begin{tabular}{|c|c|c|c|c|c|c|}
\hline Influencing factors & $\begin{array}{l}\text { Cultivated } \\
\text { land }\end{array}$ & $\begin{array}{l}\text { Forestry } \\
\text { area }\end{array}$ & Grassland & $\begin{array}{l}\text { Water } \\
\text { area }\end{array}$ & $\begin{array}{l}\text { Built-up } \\
\text { areas }\end{array}$ & $\begin{array}{l}\text { Unused } \\
\text { land }\end{array}$ \\
\hline Terrain: plain $(0,1)$ & $\begin{array}{l}0.018 \\
(0.021)\end{array}$ & $\begin{array}{l}0.198 \\
(2.44)\end{array}$ & $\begin{array}{l}0.057 \\
(2.66)\end{array}$ & $\begin{array}{l}1.009 \\
(0.39)\end{array}$ & $\begin{array}{l}0.233 \\
(3.26)\end{array}$ & $\begin{array}{l}1.638 \\
(4.26)\end{array}$ \\
\hline Terrain: mesa $(0,1)$ & $\begin{array}{l}-1.560 \\
(-19.00)\end{array}$ & $\begin{array}{l}0.394 \\
(1.71)\end{array}$ & $\begin{array}{l}-2.527 \\
(-57.22)\end{array}$ & $\begin{array}{l}6.510 \\
(2.52)\end{array}$ & $\begin{array}{l}0.343 \\
(2.09)\end{array}$ & $\begin{array}{l}5.128 \\
(13.28)\end{array}$ \\
\hline Terrain plateau $(0,1)$ & $\begin{array}{l}0.199 \\
(9.73)\end{array}$ & $\begin{array}{l}0.416 \\
(5.18)\end{array}$ & $\begin{array}{l}-0.390 \\
(-18.28)\end{array}$ & $\begin{array}{l}4.537 \\
(1.76)\end{array}$ & $\begin{array}{l}0.738 \\
(10.78)\end{array}$ & $\begin{array}{l}3.484 \\
(9.10)\end{array}$ \\
\hline Soil $\mathrm{pH}$ value & $\begin{array}{l}-3.22 \\
(-16.00)\end{array}$ & $\begin{array}{l}1.307 \\
(1.68)\end{array}$ & $\begin{array}{l}0.831 \\
(3.92)\end{array}$ & $\begin{array}{l}38.155 \\
(7.18)\end{array}$ & $\begin{array}{l}0.912 \\
(1.59)\end{array}$ & $\begin{array}{l}-1.293 \\
(-1.14)\end{array}$ \\
\hline Soil depth & $\begin{array}{l}-0.265 \\
(-7.27)\end{array}$ & $\begin{array}{l}-3.587 \\
(-14.42)\end{array}$ & $\begin{array}{l}0.323 \\
(8.47)\end{array}$ & $\begin{array}{l}-4.294 \\
(-14.00)\end{array}$ & $\begin{array}{l}-1.349 \\
(-12.43)\end{array}$ & $\begin{array}{l}-0.187 \\
(-1.17)\end{array}$ \\
\hline Elevation & $\begin{array}{l}-0.001 \\
(-8.64)\end{array}$ & $\begin{array}{l}0.006 \\
(8.52)\end{array}$ & $\begin{array}{l}0.001 \\
(2.92)\end{array}$ & $\begin{array}{l}-0.023 \\
(-25.25)\end{array}$ & $\begin{array}{l}-0.003 \\
(-9.22)\end{array}$ & $\begin{array}{l}0.017 \\
(35.08)\end{array}$ \\
\hline Slope & $\begin{array}{l}0.001 \\
(15.14)\end{array}$ & $\begin{array}{l}-0.001 \\
(-0.76)\end{array}$ & $\begin{array}{l}-0.001 \\
(-6.82)\end{array}$ & $\begin{array}{l}-0.014 \\
(-23.46)\end{array}$ & $\begin{array}{l}-0.002 \\
(-11.44)\end{array}$ & $\begin{array}{l}-0.002 \\
(-7.42)\end{array}$ \\
\hline Air temperature & $\begin{array}{l}2.039 \\
(16.73)\end{array}$ & $\begin{array}{l}7.404 \\
(12.14)\end{array}$ & $\begin{array}{l}-1.771 \\
(-14.07)\end{array}$ & $\begin{array}{l}12.609 \\
(21.27)\end{array}$ & $\begin{array}{l}2.421 \\
(6.90)\end{array}$ & $\begin{array}{l}-0.606 \\
(-1.42)\end{array}$ \\
\hline Rainfall & $\begin{array}{l}-0.008 \\
(-6.73)\end{array}$ & $\begin{array}{l}-0.103 \\
(-14.54)\end{array}$ & $\begin{array}{l}0.007 \\
(5.51)\end{array}$ & $\begin{array}{l}0.029 \\
(3.68)\end{array}$ & $\begin{array}{l}-0.024 \\
(-6.62)\end{array}$ & $\begin{array}{l}-0.029 \\
(-6.66)\end{array}$ \\
\hline $\begin{array}{l}\text { Cumulative } \\
\text { temperature }(>=0)\end{array}$ & $\begin{array}{l}-0.003 \\
(-3.13)\end{array}$ & $\begin{array}{l}-0.013 \\
(-3.11)\end{array}$ & $\begin{array}{l}0.009 \\
(10.00)\end{array}$ & $\begin{array}{l}-0.114 \\
(-12.35)\end{array}$ & $\begin{array}{l}-0.012 \\
(-5.05)\end{array}$ & $\begin{array}{l}-0.010 \\
(-3.45)\end{array}$ \\
\hline $\begin{array}{l}\text { Cumulative } \\
\text { temperature }(>=10)\end{array}$ & $\begin{array}{l}0.001 \\
(9.58)\end{array}$ & $\begin{array}{l}-0.001 \\
(-1.65)\end{array}$ & $\begin{array}{l}0.001 \\
(8.37)\end{array}$ & $\begin{array}{l}0.015 \\
(1.32)\end{array}$ & $\begin{array}{l}0.001 \\
(2.53)\end{array}$ & $\begin{array}{l}-0.015 \\
(-32.01)\end{array}$ \\
\hline Sunshine hours & $\begin{array}{l}0.397 \\
(21.91)\end{array}$ & $\begin{array}{l}0.481 \\
(5.84)\end{array}$ & $\begin{array}{l}-0.377 \\
(-20.53)\end{array}$ & $\begin{array}{l}1.299 \\
(13.07)\end{array}$ & $\begin{array}{l}0.643 \\
(13.89)\end{array}$ & $\begin{array}{l}-1.138 \\
(-20.77)\end{array}$ \\
\hline $\begin{array}{l}\text { Distance to provincial } \\
\text { capital }\end{array}$ & $\begin{array}{l}0.006 \\
(10.42)\end{array}$ & $\begin{array}{l}0.047 \\
(16.50)\end{array}$ & $\begin{array}{l}0.001 \\
(1.77)\end{array}$ & $\begin{array}{l}-0.026 \\
(-6.23)\end{array}$ & $\begin{array}{l}0.013 \\
(8.34)\end{array}$ & $\begin{array}{l}-0.027 \\
(-13.66)\end{array}$ \\
\hline Distance to highway & $\begin{array}{l}-0.021 \\
(-12.62)\end{array}$ & $\begin{array}{l}-0.119 \\
(-14.25)\end{array}$ & $\begin{array}{l}0.031 \\
(17.79)\end{array}$ & $\begin{array}{l}-0.088 \\
(-8.59)\end{array}$ & $\begin{array}{l}-0.056 \\
(-12.81)\end{array}$ & $\begin{array}{l}0.050 \\
(8.27)\end{array}$ \\
\hline
\end{tabular}


Table 3. Cont.

\begin{tabular}{lllllll}
\hline $\begin{array}{l}\text { Distance to } \\
\text { expressway }\end{array}$ & 0.016 & 0.014 & -0.002 & -0.046 & -0.013 & -0.043 \\
Population density & $(24.8)$ & $(3.80)$ & $(-3.31)$ & $(-10.36)$ & $(-7.03)$ & $(-16.25)$ \\
& 0.034 & -0.01 & -0.041 & -0.025 & -0.002 & -0.026 \\
GDP & $(23.52)$ & $(-3.78)$ & $(-252.94)$ & $(-20.43)$ & $(-14.17)$ & $(-37.23)$ \\
& -0.089 & 0.011 & 0.090 & -0.191 & 0.040 & -0.040 \\
Constant & $(219.49)$ & $(10.34)$ & $(212.67)$ & -36.09 & $(94.63)$ & $(-14.62)$ \\
& -62.17 & -28.142 & 53.852 & - & -109.035 & 331.938 \\
& $(-12.39)$ & $(-1.27)$ & $(10.47)$ & 303.115 & $(-8.44)$ & $(17.82)$ \\
Observation numbers \\
Pseudo R
\end{tabular}

\subsection{Scenarios}

A scenario analysis, closely related with the land use projections for each year during the simulation period, is of necessity to export more than one projected output and strengthen the practicability of the simulation results. According to the characteristics of land uses and regional developments, three kinds of scenarios -baseline, economic priority and environmental priority - are incorporated in DLS to simulate the dynamics of land systems of Taips County in the projection periods between 2005 and 2020 .

\subsubsection{Baseline scenario}

Baseline scenario is a reference case depicting a future state of society and/or environment in which no new environmental policies or economic policies are implemented, apart from those already in use. Most of the variables identifying the scenario are from the field survey conducted in Taips County, which reveals the circumstances of land uses in the region in 2005. A large majority of variables used to develop the baseline scenario comes from the field survey, which could be the reference to design the other two kinds of scenarios. The structure of land uses in 2010 and 2020 is derived from the land use planning of the Taips County. The land uses for each year from 2005 to 2010 and from 2010 to 2020 are calculated based on the linear interpolation within the two sections of periods, respectively.

\subsubsection{Economic priority scenario}

Under the economic priority scenario, the number of livestock would be increased to fulfill the increasing demand for meat and milk in Taips County. Under the projections that local economic growth is above the average level of the nation in this scenario, the area of cultivated land and urban land will expand at a relatively high speed. There would be a trend of intensified use of grasslands as a response to the policies of providing special subsidies for farmers who increase the number of cropping cycles on their land and the livestock numbers in Taips County. 
Under this scenario, the bare hills would be reforested and a number of effective measurements would be taken effectively to resist the steppe degradation given environmental protection concern. In addition, the reclamation of cultivated land, as well as the expansion of urban land and other built-up areas would be maintained at a lower speed.

\subsection{Dynamic simulation}

Comparing the simulated results among the baseline, the economic priority and environmental priority scenarios in the case study of Taips County, we find that there exist competition and succession among land uses due to the component effects from the influencing factors (Figure 5).

Figure 5. Projected land use situations under (a) the baseline scenario, (b) the economic priority scenario and (c) the environmental priority of Taips County.
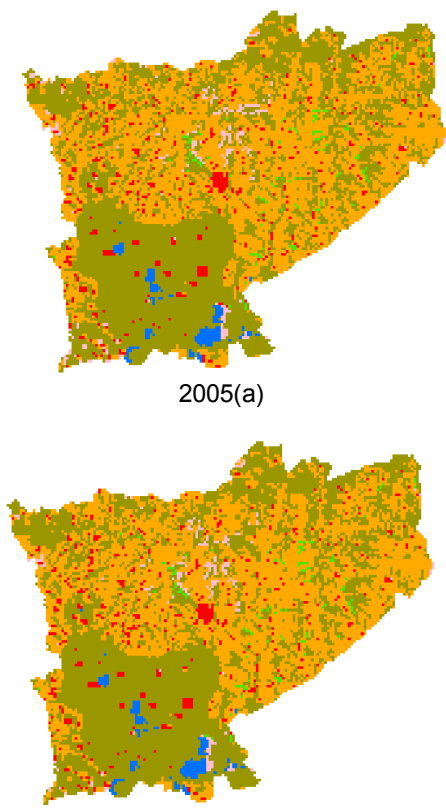

2005(b)

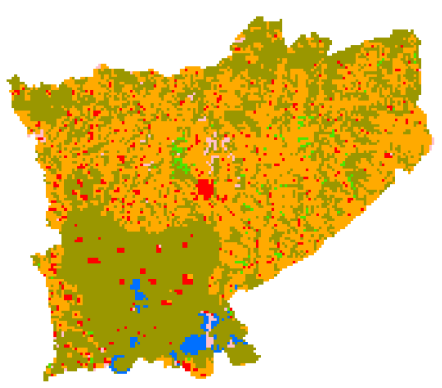

2005(c)
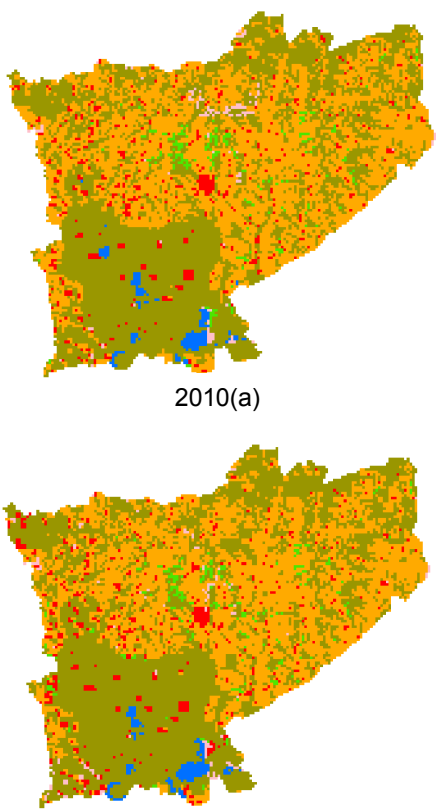

2010(b)

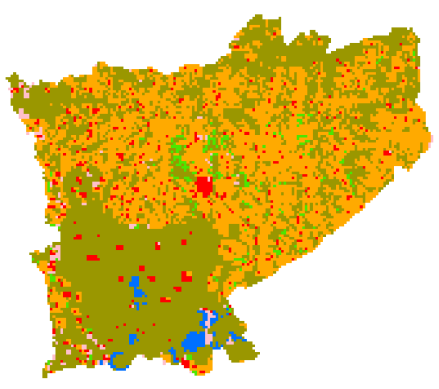

2010(c)
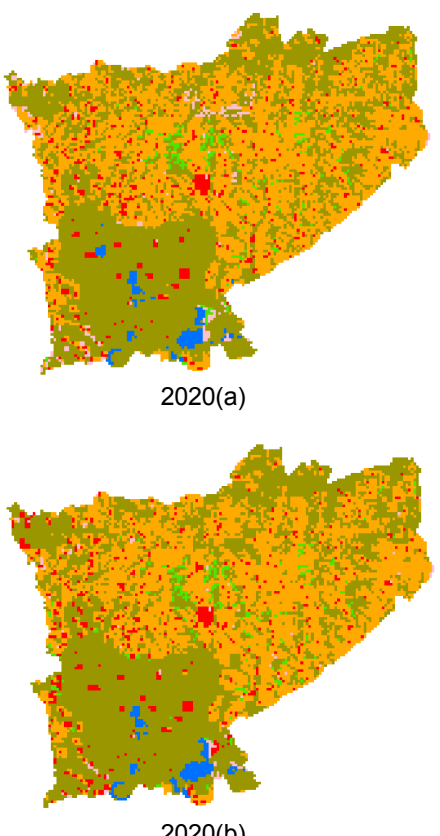

2020(b)

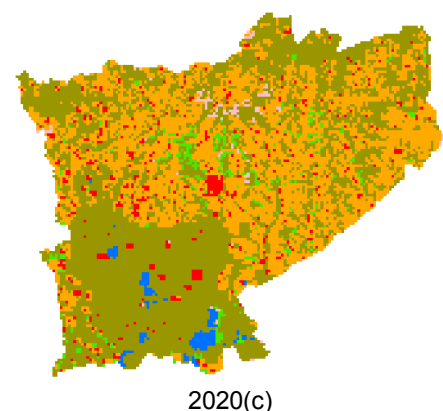

Built-up area $\square$ Unused land

Under the baseline scenario, each kind of land use would mainly expand or shrink at the vicinity of their formerly existing areas. By 2020, a large amount of unused land distributed in the northeastern Taips County would be reclaimed, except those areas where severe soil erosion was maintained intact. The expansion of forestry area would be converted from unused land located in the northeastern and 
northwestern Taips County while the spatial pattern of grassland would almost keep intact. There would be a dramatic expansion for urban and rural settlements and other built-up areas, and the newly expanded urban land would mainly be shown around the downtown area or residential centers in Taips County. Even so, there would be no large-scale, inter-connected urban areas in Taips County by the end of 2020. The area of water bodies in Taips County, affected briefly by the annual variation of precipitation, would be relatively small compared with other land uses. Therefore, the spatial distribution of water bodies would almost remain intact during the simulation period between 2005 and 2020. The shrinkage of unused land would be very large and the encroachment of cultivated land on unused land would occur in the areas where unused land is densely distributed.

Under the economic priority scenario, the shrinkage of unused land would be mostly obvious. Almost all unused land located in the northwestern and northeastern Taips County in the base year of 1988 would be converted to cultivated land, grassland or forestry areas. Although there would an increasing trend for forestry areas, the total projected areas for the three kinds of land use types would not be so high. The even distribution of forestry area in the easternmost Taips County under the environmental priority scenario would not appear under the development priority scenario. Compared with the baseline scenario, the land use change under the environmental priority scenario would be characterized by the dramatic expansion of forestry area. A considerable amount of forestry area would appear in the northwestern and northeastern Taips County in 2010 and 2020 at the same time a large

\section{Concluding remarks}

DLS provides an effective framework to simulate the dynamics of a land system. Although the model aims at a realistic description of the land use changes the results should not be interpreted as forecasts of future events. However, the simulation results indicate possible patterns of land use change under various scenarios. The exploration of dynamics of land systems and the identification of 'hotspots' of land use change can be seen as a policy-supporting instrument. By including an interface to input the spatial regression results, DLS gives users the flexibility to accurately measure the relationship between land uses and influencing factors and easily incorporate the estimated results obtained by specifying more robust spatial econometric functions. The issues on co-linearity between the explanatory variables and impacts from the time variant variables on land use changes are considered and handled. In addition, the uncertainty resulting from the reduction of the complexity inherent in land systems could be reduced by supplying more flexible interface for users to input the spatial regression results with more robust model specification and by developing more than one kinds of scenarios to simulate the dynamics of land systems under various conditions.

The simulations of the dynamics of land systems in Taips County under three kinds of scenarios uncover the dynamics of land systems along various land use trajectories, which helps to target management decisions on rational land uses and effective environment protections of Taips County. First, in according to the simulation results and given the situation of grassland degradation and land desertification, we suggest that the local government of Taips County should develop overall land use planning to achieve a rational exploitation of land resources, adjust the economic structure, and to control the population growth and adjust the development paths of economy. Second, the simulation results show the northwestern and northeastern Taips County, which was mostly covered by unused 
land in the base year of 1988, would become the most sensitive area for land-use changes in the simulation periods, as warn us to pay more attention to land use change in this area and take effective measures to mange the land uses for that area.

DLS may also offer a tool to integrate multiple data sources to assess pathways of development and related effects of land use changes and can easily be applied to a wide range of study areas, one main limitation of DLS is that it has not supplied an interface for users to parameterize local characteristics on land uses to simulate the dynamics of land systems in those areas without a land use change history. This is because the model uses estimated relations based on existing land uses for the allocation of land use changes. One possible way to overcome this limitation is to incorporate one input window for users to introduce prior knowledges or adjustments on land conversions of the study area, as might be solved in the next version of DLS.

\section{Acknowledgements}

The authors would like to thank Jiyuan Liu for comments on earlier versions of this manuscript. This research was supported by the National Scientific Foundation of China (70503025), the Chinese Academy of Sciences (KSCX2-YW-N-039; KZCX2-YW-305-2) and the Ministry of Science and Technology of China (2006DFB919201; 2006BAC08B06).

\section{References and Notes}

1. Turner II, B.L.; Skole, D.; Sanderson, S.; Fischer, G.; Fresco, L.; Leemans, R. Land-Use and Land-Cover Change. Science/Research Plan: Stockholm and Geneva, 1995.

2. Veldkamp, A.; Fresco. L.O. Exploring land use scenarios, an alternative approach based on actual land use. Agric. Syst. 1997, 55, 1 - 17.

3. Global Land Project. Science Plan and Implementation Strategy. GLP: Stockholm, 2005. 64 pages.

4. Verburg, P.H.; Veldkamp, A. Introduction to the special issue on spatial modeling to explore land use dynamics. Int. J. Geog. Info. Sci. 2005, 19, 99 -102.

5. Verburg, P.H.; de Konig, G.H.J.; Kok, K.; Veldkamp, A.; Bouma J. A spatial explicit allocation procedure for modeling the pattern of land use change based upon actual land use. Ecol. Model. 1999, 116, $45-61$.

6. Agarwal, C.; Green, G.M.; Grove, J.M.; Evans, T.P.; Schweik, C.M. A review and assessment of land-use change models: dynamics of space, time, and human choice. USDA Forest Service PA, USA, 2002. 61 pages.

7. Kok, K.; Patel, M.; Rothman, D.S.; Quaranta, G. Multi-scale narratives from an IA perspective: Part II. Participatory local scenario development. Futures 2006, 38, 285 - 311.

8. Verburg, P.H.; Rounsevell, M.D.A.; Veldkamp, A. Scenario-based studies of future land use in Europe. Agric. Ecosyst. Environ. 2006, 114, 1 - 6.

9. Veldkamp, A.; Fresco. L.O. CLUE: a conceptual model to study the conversion of land use and its effects. Ecol. Model. 1996, 85, 253 - 270. 
10. Ligtenberg, A.; Bregt, A.K.; Lammeren, R.V. Multi-actor-based land use modeling: spatial planning using agents. Landscape Urban Plan. 2001, 56, 21 - 33.

11. Bah, A.; Toure. I.; Le Page, C.; Ickowicz, A.; Diop, A.T. An agent-based model to understand the multiple uses of land and resources around drillings in Sahel. Math. Comp. Model. 2006, 44, 513 534.

12. Dietzel, C.; Clarke, K. The effect of disaggregating land use categories in cellular automata during model calibration and forecasting. Comp. Environ. Urban Syst. 2006, 30, 78 - 101.

13. Kok, K.; Verburg, P.H.; Veldkamp, T. Integrated Assessment of the land system: The future of land use. Land Use Policy 2007, 24, 517 - 520.

14. Batty, M.; Xie, Y.; Sun, Z. Modeling urban dynamics through GIS-based cellular automata. Comp. Environ. Urban Syst. 1999, 23, 205 - 233.

15. Castella, J.C.; Verburg, P.H. Combination of process-oriented and pattern-oriented models of land-use change in a mountain area of Vietnam. Ecol. Model. 2007, 202, 410 - 420.

16. Chen, Y.; Verburg, P.H.; Xu, B. Spatial modeling of land use and its effects in China. Prog. Geograph. 2000, 19, 116 - 127.

17. Verburg, P.H.; Soepboer, W.; Veldkamp, A.; Limpiada, R.; Espaldon, V. Modeling the spatial dynamics of regional land use: the CLUE-S model. Environ. Manag. 2002, 30, 391 - 405.

18. Yue, T.X.; Wang, Y.A.; Liu, J.Y.; Chen, S.P.; Qiu, D.S.; Deng, X.Z.; Liu, M.L.; Tian, Y.Z. Su. B.P. Surface modeling of human population distribution in China. Ecol. Model. 2005, 181, 461 478.

19. Doll, C.N.H.; Muller, J. P.; Morley, J.G. Mapping regional economic activity from night-time light satellite imagery. Ecol. Econ. 2006, 57, 75 - 92.

20. Price, D.T.; McKenney, D.W.; Nalder, I.A.; Hutchinson, M.F.; Kesteven, J.L. A comparison of two statistical methods for spatial interpolation of Canadian monthly mean climate data. Agric. For. Meteorol. 2000, 101, 81 - 94.

21. Jeffrey, S.J.; Carter, J.O.; Moodie, K.B.; Beswick, A.R. Using spatial interpolation to construct a comprehensive archive of Australian climate data. Environ. Model. Soft. 2001, 16, 309 - 330.

22. Hutchinson, M.F. Stochastic space-time weather models from ground-based data. Agric. For. Meteorol. 1995, 73, 237 - 264.

(C) 2008 by MDPI (http://www.mdpi.org). Reproduction is permitted for noncommercial purposes. 